\title{
Effect of Losartan and Atenolol on Lung Function Status in Newly Diagnosed Essential Hypertensive Patients
}

\author{
Nahar $\mathrm{MN}^{1}$, Begum $\mathrm{S}^{2}$, Ferdousi $\mathrm{S}^{3}$, Sultana $\mathrm{S}^{4}$, Parveen $\mathrm{Z}^{5}$
}

\begin{abstract}
Introduction: Essential hypertension is associated with altered pulmonary function. Antihypertensive medication and lung function are also associated. Losartan (angiotensin II receptor blocker) and atenolol (beta blocker) are commonly used antihypertensive drugs.
\end{abstract}

Objective: To evaluate the effects of antihypertensive drugs on lung function status in patients with essential hypertension.

Methods: This prospective observational study was carried out in the Department of Physiology of Bangabandhu Sheikh Mujib Medical University (BSMMU), Shahbag, Dhaka, from July 2012 to June 2013 on 100 newly diagnosed essential hypertensive patients who had not received any antihypertensive medications. They were selected from the Out Patient Department (OPD) of Cardiology unit, BSMMU, Dhaka. The study sbujects of age between 30-55 were allocated in group B. Based on prescribed treatment, these study subjects were divided into two groups - B1 and B2. B1 included 50 patients who received losartan $50 \mathrm{mg}$ daily and $\mathrm{B} 2$ included 50 patients who received atenolol $50 \mathrm{mg}$ daily. Again basing on duration of treatment group B1 was divided into B1a (newly diagnosed hypertensive patients before treatment), B1b (after 3 months of medication with losartan) and B1C (after 6 months medication with losartan). Similarly group B2 was divided into $\mathrm{B} 2 \mathrm{a}, \mathrm{B} 2 \mathrm{~b}$, and B2c. For assessing lung function status, FVC, FEV1 and PEFR were measured with acomputer based Spirometer. Age, sex and BMI matched 50 apparently healthy normotensive subjects were also studied as control (group A). Data were compared among subjects of different groups. For statistical analysis independent sample ' $\mathrm{t}$ ' test and paired sample 't' test were performed.
Results: Mean systolic blood pressure and diastolic blood pressure were significantly higher and mean FVC, FEV 1 and PEFR were significantly lower in newly diagnosed hypertensive patients in comparison with that of healthy normotensive subjects. Mean FVC and $\mathrm{FEV}_{1}$ were found significantly higher in the group taking losartan for 6 months when compared to newly diagnosed hypertensive patients but lower than those of controls. In addition, mean FVC and $\mathrm{FEV}_{1}$ were found significantly lower in the group taking atenolol for 6 months when compared to newly diagnosed hypertensive patients and those of controls.

Conclusion: Reduced lung function occurs in newly diagnosed essential hypertensive patients which improves by treatment with losartan but decreases after treatment with atenolol.

Key-words: Newly diagnosed essential hypertensive patients, lung function status, antihypertensive drugs.

\section{Introduction}

Hypertension is a sustained elevation of systemic arterial pressure ${ }^{1}$. Essential hypertension accounts for $90-95 \%$ of all cases of hypertension. Essential hypertension means hypertension which is of unknown origin ${ }^{2}$. Now a days, hypertension has become a significant public health challenge throughout the world because of its high prevalence ${ }^{3}$. In Bangladesh the prevalence rate of hypertension is also very high and more than $20 \%$ of the adults have hypertension ${ }^{4}$. Hypertension has been linked to multiple other diseases including cardiac, cerebrovascular, renal and eye diseases ${ }^{5}$. Several studies showed that hypertension and lung function are also associated ${ }^{6,7,8,9,10,11}$. In addition, a wide variety of antihypertensive drugs are now available with

1. Maj. Mst Nasrin Nahar, MBBS, MD(Physiology), Asst Prof of Physiology, AFMC, Dhaka; 2. Prof Shelina Begum, MBBS, MPhil, Prof and Chairman of Physiology, BSMMU, Shahbag, Dhaka; 3. Assoc Prof Sultana Ferdousi, MBBS, MPhil, Department of Physiology, BSMMU, Shahbag, Dhaka. 4. Lt Col Sharmeen Sultana, MBBB, MPhil, Department of Physiology, AFMC, Dhaka; 5. Lt Col Zinia Parveen, MBBB, MPhil, Department of Physiology, AFMC, Dhaka. 
different mechanisms of action and certain antihypertensive drugs can affect pulmonary function. A randomized controlled trial have shown that angiotensin II receptor blocker has no effect on $\mathrm{FEV}_{1}$ or airway resistance in COPD patients ${ }^{12}$. Another study revealed that angiotensin II receptor blocker slightly reduces bronchial hyperresponsiveness to methacholine in patients with bronchial asthma $^{13}$. Few studies revealed that relatively cardioselective agents have been considered contraindicated in patients with asthma or COPD, as these may produce bronchoconstriction and thereby worsen respiratory flows and symptoms in these patients $^{14,15}$. On the other hand, two systematic reviews of randomized controlled trials revealed that the cardioselective beta blocker has no adverse effect on lung functions in patients with asthma or COPD $^{16,17}$.

Although several investigators observed the effect of losartan and atenolol on lung function separately, no report compared the effect of losartan and atenolol on lung function in newly diagnosed hypertensive patients. Therefore this study aimed to evaluate the lung function in newly dignosed hypertensive patients and compare the effects of losartan and atenolol on lung function.

\section{Methods}

This prospective observational study was carried out in the Department of Physiology of Bangabandhu Sheikh Mujib Medical University (BSMMU), Shahbag, Dhaka, from July 2012 to June 2013. Hundred newly diagnosed hypertensive patients aged between 30-55 years were selected as study group. Age, sex and BMl matched 50 apparently healthy normotensive subjects were also studied as control (group A). Based on treatment, these study subjects were divided into two groups; B1 and B2. $B 1$ included 50 patients who received losartan $50 \mathrm{mg}$ daily and B2 included 50 patients who received atenolol 50mg daily. Again group B1 was divided into - $\mathrm{B} 1_{\mathrm{a}}$ (newly diagnosed hypertensive patients before treatment), $\mathrm{B}_{\mathrm{b}}$ (after 3 months of medication with losartan) and $\mathrm{B} 1_{\mathrm{C}}$ (after 6 months medication with losartan). Similarly subjects of group B2 were divided into $\mathrm{B} 2 \mathrm{a}$ (newly diagnosed hypertensive patients before treatment), B2 $b$ (after 3 months of medication with atenolol) and $\mathrm{B}_{\mathrm{C}}$ (after 6 months medication with atenolol). These patients were selected from the Out Patient Department of Cardiology unit, BSMMU.

Subjects with history of acute or chronic lung and chest wall disease e.g. pneumonia, tuberculosis, asthma, COPD, malignancy etc, and with history of coronary heart disease, diabetes mellitus and also the alcohol/tobacco users and smokers were excluded from the study. After random selection of the subjects a detail personal, medical, family, socioeconomic, occupational and drug history were recorded in a preformed questionnaire and thorough physical examinations were done and documented. For the assessment of lung function, FVC, FEV 1 and PEFR were measured with a computer based Spirometer.

Then all the patients were requested to attend Department of Physiology, BSMMU again after 3 months and after 6 months of antihypertensive medication to have the assessment of the above mentioned study variables. For statistical analysis independent sample 't' test and paired sample 't' test were performed by using SPSS (statistical package for social sciences) for windows version 16.0 as applicable. $P$ value $<0.05$ was accepted as level of significance.

Table-I: Percentages of predicted values of FVC, $\mathrm{FEV}_{1}$ and PEFR in different groups $(\mathrm{n}=100)$.

\begin{tabular}{|l|c|c|c|c|}
\hline Parameters & $\begin{array}{c}\text { Group } A \\
(\mathrm{n}=50)\end{array}$ & $\begin{array}{c}\mathrm{B}_{\mathrm{a}} \\
(\mathrm{n}=50)\end{array}$ & $\begin{array}{c}\mathrm{B} 1_{\mathrm{b}} \\
(\mathrm{n}=50)\end{array}$ & $\begin{array}{c}\mathrm{B} 1_{\mathrm{c}} \\
(\mathrm{n}=50)\end{array}$ \\
\hline FVC $(\mathrm{L})$ & $88.9 \pm 0.827$ & $75.46 \pm 1.171$ & $76.84 \pm 0.993$ & $79.66 \pm 1.139$ \\
\hline $\mathrm{FEV}_{1}(\mathrm{~L})$ & $90.62 \pm 0.772$ & $79.58 \pm 1.144$ & $81.16 \pm 1.082$ & $83.96 \pm 1.198$ \\
\hline PEFR $(\mathrm{L} / \mathrm{s})$ & $78.38 \pm 1.373$ & $76.38 \pm 1.527$ & $76.54 \pm 1.476$ & $78.9 \pm 1.369$ \\
\hline
\end{tabular}

Statistical analysis

\begin{tabular}{|c|c|c|c|}
\hline \multirow{2}{*}{ Groups } & \multicolumn{3}{|c|}{$P$ value } \\
\hline & FVC & $\mathrm{FEV}_{1}$ & PEFR \\
\hline$A$ vs $B 1 a^{\varphi}$ & $0.000^{* * *}$ & $0.000^{* * *}$ & $0.333^{\text {ns }}$ \\
\hline$A$ vs $B 1 b^{\varphi}$ & $0.000^{\star \star \star}$ & $0.000^{\star \star \star}$ & $0.364^{\mathrm{ns}}$ \\
\hline$A$ vs $B 1 c^{\varphi}$ & $0.000^{\star * *}$ & $0.000^{* * *}$ & $0.789^{\text {ns }}$ \\
\hline $\mathrm{B} 1 \mathrm{a}$ vs $\mathrm{B} 1 \mathrm{~b}^{\Omega}$ & $0.04^{*}$ & $0.000^{\star \star \star}$ & $0.881^{\mathrm{ns}}$ \\
\hline $\mathrm{B} 1 \mathrm{~b}$ vs $\mathrm{B} 1 \mathrm{c}^{\Omega}$ & $0.000^{* * *}$ & $0.000^{* * *}$ & $0.009^{* *}$ \\
\hline $\mathrm{B} 1 \mathrm{a}$ vs $\mathrm{B} 1 \mathrm{c}^{\Omega}$ & $0.000^{\star \star *}$ & $0.000^{\star \star *}$ & $0.059^{\text {ns }}$ \\
\hline
\end{tabular}


Data were expressed as mean \pm SE.

$\varphi=$ independent sample't' test,

$\Omega=$ Paired sample 't' test

Group A : Apparently healthy subjects (control group)

Group $\mathrm{B} 1_{\mathrm{a}}$ : Newly diagnosed hypertensive patients before treatment

Group $\mathrm{B} 1_{\mathrm{b}}$ : After 3 months treatment with losartan

Group B1 $\mathrm{C}$ : After 6 months treatment with losartan

$* * *$ : Significant $(p \leq 0.001)$,

** : Significant $(p \leq 0.01)$

* : Significant $(p \leq 0.05)$,

ns : Nonsignificant,

$\mathrm{n}$ : Number

The mean of the percentages of predicted values of FVC, FEV1 and PEFR were significantly lower in group $\mathrm{B} 2_{\mathrm{a}}, \mathrm{B} \mathrm{b}_{\mathrm{b}}$ and $\mathrm{B} 2_{\mathrm{c}}$ respectively than those of control. In addition, the mean percentage of predicted values of $\mathrm{FVC}$ and $\mathrm{FEV}_{1}$ were significantly decreased in group $\mathrm{B} 2_{b}$ and $\mathrm{B}_{\mathrm{C}}$ in comparison to their corresponding base line value $\mathrm{B} 1_{\mathrm{a}}$. But the mean percentage of predicted value of PEFR was nonsignificantly increased in group B2b and B2C in comparison to their corresponding base line values of group B2 $\mathrm{a}$ (table-II).

Table-II: Percentages of predicted values of FVC, FEV1and PEFR in different groups $(n=100)$.

\begin{tabular}{|c|c|c|c|c|}
\hline Parameters & $\begin{array}{c}\text { Group A } \\
(\mathrm{n}=50)\end{array}$ & $\begin{array}{c}\mathrm{B}_{a} \\
(\mathrm{n}=50)\end{array}$ & $\begin{array}{c}\mathrm{B} 2_{b} \\
(\mathrm{n}=50)\end{array}$ & $\begin{array}{c}\mathrm{B} 2_{c} \\
(\mathrm{n}=50)\end{array}$ \\
\hline FVC $(\mathrm{L})$ & $88.9 \pm 0.827$ & $74.72 \pm 0.786$ & $72.84 \pm 0.997$ & $71.42 \pm 1.028$ \\
\hline $\mathrm{FEV}_{1}(\mathrm{~L})$ & $90.62 \pm 0.772$ & $79.04 \pm 1.079$ & $76.88 \pm 1.248$ & $75.62 \pm 1.298$ \\
\hline PEFR $(\mathrm{L} / \mathrm{s})$ & $78.38 \pm 1.373$ & $74.36 \pm 1.444$ & $75.28 \pm 1.353$ & $76.6 \pm 1.302$ \\
\hline
\end{tabular}

Statistical analysis

\begin{tabular}{|c|c|c|c|}
\hline \multirow{2}{*}{ Groups } & \multicolumn{3}{|c|}{$P$ value } \\
\hline & FVC & $\mathrm{FEV}_{1}$ & PEFR \\
\hline$A$ vs $B 2 a^{\varphi}$ & $0.000^{* \star *}$ & $0.000^{* * *}$ & $0.046^{*}$ \\
\hline$A$ vs $B 2 b^{\varphi}$ & $0.000^{* \star *}$ & $0.000^{\star \star \star}$ & $0.111^{\mathrm{ns}}$ \\
\hline$A$ vs $B 2 c^{\varphi}$ & $0.000^{\star \star \star}$ & $0.000^{\star \star \star}$ & $0.349^{\text {ns }}$ \\
\hline B2a vs B2b ${ }^{\Omega}$ & $0.000^{* * *}$ & $0.000^{\star * *}$ & $0.317^{\mathrm{ns}}$ \\
\hline B2bvs B2c ${ }^{\Omega}$ & $0.000^{* * *}$ & $0.042^{*}$ & $0.154^{* *}$ \\
\hline B2a vs B2c ${ }^{\Omega}$ & $0.000^{* * *}$ & $0.000^{* * *}$ & $0.035^{*}$ \\
\hline
\end{tabular}

Data were expressed as mean $\pm S E$.

$\varphi=$ independent sample 't' test,

$\Omega=$ Paired sample 't' test

Group A : Apparently healthy subjects (control group)

Group $\mathrm{B} 2 \mathrm{a}$ : Newly diagnosed hypertensive patients before treatment

Group B2b : After 3 months treatment with atenolol Group B2 $\mathrm{C}$ : After 6 months treatment with atenolol

$* * *$ : Significant $(p \leq 0.001)$,

** : Significant $(p \leq 0.01)$

* : Significant $(p \leq 0.05)$,

ns : Nonsignificant,

$\mathrm{n}$ : Number

\section{Discussion}

In the present study, values of the lung function parameters in healthy normotensive group were almost similar to other investigators ${ }^{7}$. The mean of the percentages of predicted values of $\mathrm{FVC}, \mathrm{FEV}_{1}$ and PEFR were significantly lower in newly diagnosed essential hypertensive patients than those of apparently healthy subjects; similar findings were also reported by investigators of other countries $^{6,7,8,10,11,18,19}$. Again in this study the lower values of the mean percentages of predicted values of $\mathrm{FVC}$ and $\mathrm{FEV}_{1}$ were significantly increased after 3 months and 6 months treatment with losartan; no similar findings were reported by other researchers. But the lower values of these two parameters were further reduced after 3 months and 6 months treatment with atenolol; similar findings in these two parameters were also reported by various investigators of different countries ${ }^{15,20}$. In addition, the lower values of the mean percentages of predicted value of PEFR was nonsignificantly improved after 3 months and 6 months treatment with losartan, but significantly increased after treatment with atenolol; no similar findings were reported by other researchers. Investigators suggested that the decrement of different ventilatory variables in essential hypertension may be associated with early left ventricular hypertrophy and moderate left ventricular dysfunction which may increase left atrial pressure. As a consequence, an elevation of pulmonary arterial pressure and interstitial oedema in the lung leading to decreased compliance of the lung and mild restrictive disease ${ }^{5,6,7}$. 
Different investigators emphasazied on the role of various mechanisms for the improvement of lung function status in hypertensive patients after treatment with losartan. Angiotensin II causes contraction of smooth muscle in pulmonary arteries and veins ${ }^{1}$. It has been suggested that angiotensin II causes bronchoconstriction in mildly asthmatic patients possibly by a direct effect on airway smooth muscle or by release of bronchoconstrictor mediators such as endothelin ${ }^{21}$. Therefore Angiotensin II receptor blocker may reduce bronchoconstriction in symptomatic asthma patients $^{22}$.

Again, different investigators ovserved the role of various mechanisms for the decrement of lung function status in hypertensive patients after treatment with atenolol. In the respiratory system, Beta 2 adrenergic receptors ( $\beta 2$-ARs) represent $70 \%$ of all Beta adrenergic receptors ( $\beta-A R$ ), with the Beta1 adrenergic receptors ( $\beta 1$-ARs) accounting for the remainder.

It has been suggested that bronchodilatation is mediated by autonomic beta-adrenoceptors, the dominant subtype being $\beta 2$. Cardioselectivity of beta blocker is dose dependent, with competitive antagonism of both $\beta 1$ and $\beta 2$ adrenoceptors at higher plasma concentrations. Therefore with higher doses of cardioselective beta-blockers, $\beta 2$ receptor blockade may cause minor increases in airflow obstruction possibly through unopposed parasympathetic bronchoconstriction ${ }^{23}$. Furthermore, beta-agonist improves the performance of skeletal muscles and also positively affects respiratory muscle strength ${ }^{24,25,26}$. Therefore Beta blocker medication may result in a slight reduction of expiratory muscle strength causing a proportional decrease of $F E V_{1}$ and $F V C^{5}$.

The exact mechanisms involved for the decrement of lung functions in hypertension and improvement after treatment with losartan but not with atenolol in hypertensive groups of present study cannot be elucidated from this type of study. However, it is assumed that all the above mentioned mechanisms may influence the degree of deterioration of these variables in hypertensive patients and improvement after treatment with losartan but not with atenolol.

\section{Conclusion}

The ventilatory variables decrease in newly diagnosed patients with essential hypertension and lung function status improves after treatment with losartan but decreases after treatment with atenolol. Apart from the suggested mechanism by several investigators these decrement may be associated with silent pulmonary disorders without presenting any pulmonary symptoms.

\section{References}

1. BarrettKE, Barman SM, Boitano S, Brooks HL.Ganong's Review of Medical Physiology. 23rd ed. India: Tata McGraw Hill: 2010.p. 544, 547, 557, 559, 587.

2. Guyton AC, Hall JE. Textbook of Medical Physiology. 12th ed. Singapore: Saunders Elsevier: 2011.p. 173, 230-231, 465-526p.

3. Kearney PM, Whelton M, Reynolds K, Whelton PK, He J. Worldwide prevalence of hypertension: a systematic review. J Hypertens 2004; 22 (1): 11-9.

4. Shahriar I, Haque Z, Momen A. Patterns of antihypertensive drugs used in two postgraduate instituitions. Journal of Dhaka National Medical College and Hospital 2008; 13 (1): 41-4.

5. Schnabel E, Nowak D, BrascheS,Wichmann HE, Heinrich J. Association between lung function, hypertension and blood pressure medication. Respiratory Medicine 2011; 105: 727-33.

6. Sparrow D, Weiss ST, Vokonas PS, Cupples LA, Ekerdt DJ, Colton T. Forced vital capacity and the risk of hypertension. The normative aging study. Am J Epidemiol 1988; 127 (4): 734-41.

7. Selby JV, Friedman GD, Quesenberry CP Jr. Precursors of essential hypertension: pulmonary function, heart rate, uric acid, serum cholesterol, and other serum chemistries. Am J Epidemiol 1989; 131 (6): 1017-27.

8. Enright PL, Kronmal RA, Smith VE, GardinJM,Schenker MB, Manolio TA. Reduced vital capacity in elderly persons with hypertension, coronary heart disease, or left ventricular hypertrophy: the cardiovascular health study. Chest 1995; 107 (1): 28-35.

9. Wu Y, Vollmer WM, Buist AS, Tsai R, Cen R, Wu X, Chen P, Li Y, Guo C, Mai J, Davis CE. Relationship between lung function and blood pressure in Chinese men and women of Beijing and Guangzhou. Int $\mathrm{J}$ Epidemiol 1998; 27: 49-56.

10. Engstrom G, Wollmar P, Valind S, Hedblad B, Janzon L. Blood pressure increases between 55 and 68 years of age is inversely related to lung function: longitudinal results from the cohort study Men born in 1914. J Hypertens 2001; 19: 1203-8. 
11. Margretardottir OB, Thorleifsson SJ, Gudmundsson G, Olafsson I, Benediktsdottir B, Janson C, Buist AS, Gislason T. Hypertension, systemic inflammation and body weight in relation to lung function impairment: an epidemiological study. COPD 2009; 6 (4): 250-5.

12. Andrease $S$, Herrmann-Lingen $C$, Raupach $T$, Luthje $L$, Fabricius JA, Hruska N, Korber W, Buchner B, Criee CP, Hasenfub G, Calverley P. Angiotensin II blockers in obstructive pulmonary disease: a randomized controlled trial. EurRespir J 2006; 27: 972-9.

13. Tanaka H, Teramoto S, Oashi K, Saikai T, Tanaka S, Suzuki K, Hashimoto M, Abe S. Effects of candesarton on cough and bronchial hyperresponsiveness in mildly to moderately hypertensive patients with symptomatic asthma. Circulation 2001; 104: 281-5.

14. Doshan HD, Rosenthal RR, Brown R, Slutsky A, Applin WJ, Caruso FS.Celiprolol, atenolol, and propranolol: a comparison of pulmonary effects in asthmatics patients. J CardiovascPharmacol 1986; 8 (Suppl 4): S105-S8.

15. Van Zyl AL, Jennings AA, Bateman ED, Opie LH. Comparison of respiratory effects of two cardioselective beta-blockers, celiprolol and atenolol, in asthmatics with mild to moderate hypertension. Chest 1989; 95 (1): 209-13.

16. Salpeter S, Ormiston T, Salpeter E. Cardioselective beta-blockers for reversible airway disease. Cochrane Database Syst Rev 2002; 1: CD002992.

17. Salpeter S, Ormiston T, Salpeter E. Cardio- selective beta-blockers for chronic obstructive pulmonary disease. Cochrane Database Syst Rev 2005; 1: CD003566.

18. Lindgarde F, Furo M, Ljung BO. A longitudinal study on the significance of environmental and individual factors associated with the development of essential hypertension. J EpidemiolComm Health 1987; 41: 220-6.
19. Schroeder EB, Welch VL, Couper D, Nieto FJ, Liao D, Rosamond WD, Heiss G. Lung function and incident coronary heart disease. Am J Epidemiol 2003; 158 (12): 1171-81.

20. Lawrence DS, Sahay JN, Chatterjee SS et al. $\beta$-blockers in asthma. Drugs 1983; 25: 232-6.

21. Millar EA, Angus RM, Hulks $G$ et al. Activity of the renin angiotensin system in acute severe asthma and the effect of angiotensin II on lung function. Thorax 1994; 49: 492-5.

22. Myou S, Fujimara M, Kamio $Y$ et al. Effect of losartan, a type 1 angiotensin II receptor antagonist, on bronchial hyperresponsiveness to methacholine in patients with bronchial asthma. Am J RespirCrit Care Med 2000; 162: 40-4.

23. Hawkins etal.Bisoprolol in patients with heart failure and moderate to severe chronic obstructive pulmonary disease: a randomized controlled trial. European Journal of Heart Failure 2009; 11: 684-90.

24. Martineau L, Horan MA, Rothwell NJ, Little RA Salbutamol, a beta 2-adrenocrptor agonist, increases skeletal muscle strength in young men. ClinSci (London) 1992; 83 (5): 615-21.

25. Grimm DR, Schilero GJ, Spungen AM, Bauma WA, Lesser M.Salmeterol improves pulmonary function in persons with tetraplegia. Lung 2006; 184 (6): 335-9.

26. Angulo M, Taranto E, Soto JP, Malacrida L, Nin N, Hurtado FJ, Pirij H. Salbutamol improves diaphragmatic contractility in chronic airway obstruction. Arch Bronconeumol 2009; 45 (5): 230-4. 